\title{
Unveiling the potentialities of urban space in Putrajaya
}

\author{
Q. Norhisham, Y. Rahman \& S. S. Zubir \\ Center of Studies for Architecture, Faculty of Architecture, Planning and \\ Surveying, Universiti Teknologi MARA, Malaysia
}

\begin{abstract}
In 1995, Malaysia embarked on a project to build the new federal government administrative city, Putrajaya. The city will be exemplary of a tropical city that will eventually become the model for new green cities in Malaysia. Initially, the focus was only on projecting a powerful image by desired physical and spatial structure through the macro scale scope of the master plan. On the ground, the completed parcels of the various precincts have not achieved the expected image of a Garden City mainly due to the extensive network of roads and the excessive projection of architectural imagery to evoke a mnemonic sense of place. This paper intends on summarizing an urban design exercise at Dataran Rakyat (The People's Square) which is one of the four public squares embellishing the $4.2 \mathrm{~km}$ Boulevard of Putrajaya's Core Island. The square is flanked by two parks, namely Taman Rakyat 1 and 2 connecting both the eastern and western portions of the waterfront, which are crucial as they will be the main transit hubs connecting the two monorail lines. The centrality of the park is vital for the urban intervention to further enliven the city. The intervention will anchor upon monumental urban spaces that act as a political device that instils a sense of patriotism for Malaysian. The legacy of our prime ministers will be resurrected through built form dedicated as a public space for all. The proposed intervention embodies the leader ideologies, thought and visions for the nation to be appreciated by future generations. The new orchard park will be a fine example of urban landscape that merges into a seamless symbiosis that enhances Putrajaya's image as a Garden City. A huge measure of sustainable systems has been appropriated in the scheme, upholding Putrajaya as the leading green city in the world. The merger between build form and landscape bring strong
\end{abstract}


attachment between man, god and nature, as it was originally intended to be the soul of the city establishment.

Keywords: Garden City, symbiosis, public space, boulevard.

\section{Introduction}

Putrajaya was designated as the new administrative centre of Malaysia as the Central Government decided to relocate the federal administrative capital from Kuala Lumpur to the district of Sepang in Selangor. Putrajaya is a model city planned with "great respect for the environment" The city is planned to embrace two main themes, city in a garden and an intelligent city. The planning and development of the new city is guided by the "Garden City" concept guidelines [1]. A master plan was subsequently prepared based on this concept. The Putrajaya Master Plan was approved by the Government in February 1995. Putrajaya Holdings Sdn. Bhd., a government listed company, was established to be the master developer of the city. The Putrajaya Master Plan covers an area of 4,931 hectares. The Garden City concept is clearly portrayed with a 37\% of land area dedicated for green and open spaces within the city.

Among the key features of the Putrajaya Master Plan is $4.2 \mathrm{~km}$ long boulevard that forms the central spine of the city and designated a large portion of the city as green open spaces. The city is divided into 20 precincts with the core employment and commercial precincts located on an island surrounded by the man-made lake and wetlands. Therefore, a 38 kilometres long waterfront area is formed with the creation of the lake.

The main objective of this design escapade is to generate creative and practical ideas to re-enliven the existing urban spaces in the Core Precincts of Putrajaya. The exercise will result with viable proposal concepts that reflect vibrant, sustainable and successful urban places.

Among others, the proposal has taken into consideration the following:

i. A viable master plan that is responsive to the existing and future needs of the community and end users.

ii. The proposal has to be environmentally friendly. Adoption of sustainable approaches to design such as the Malaysian Green Building Index and Zero Carbon Footprint.

iii. A development proposal that addresses the infrastructural, economic and social issues faced by the end-users/community.

iv. Generating interesting concepts that further enhance the Garden City image in the urban space design proposals.

\section{Site background, Putrajaya}

Dataran Rakyat is flanked by two parks, namely Taman Rakyat 1 and 2 (figure 1) creating the axis of the people. Informative boards containing descriptive writings about our former Prime Ministers, as well as procurable information of flora and fauna within the vicinity of Putrajaya are set along the park. This stretch of open public space connecting both the eastern and western sectors of the waterfronts (figure 2) holds a crucial role in the future Putrajaya 
development as it will become the main transit hub connecting two intersecting monorail lines. The centrality of the site provides a much needed urban intervention to further enliven the city.

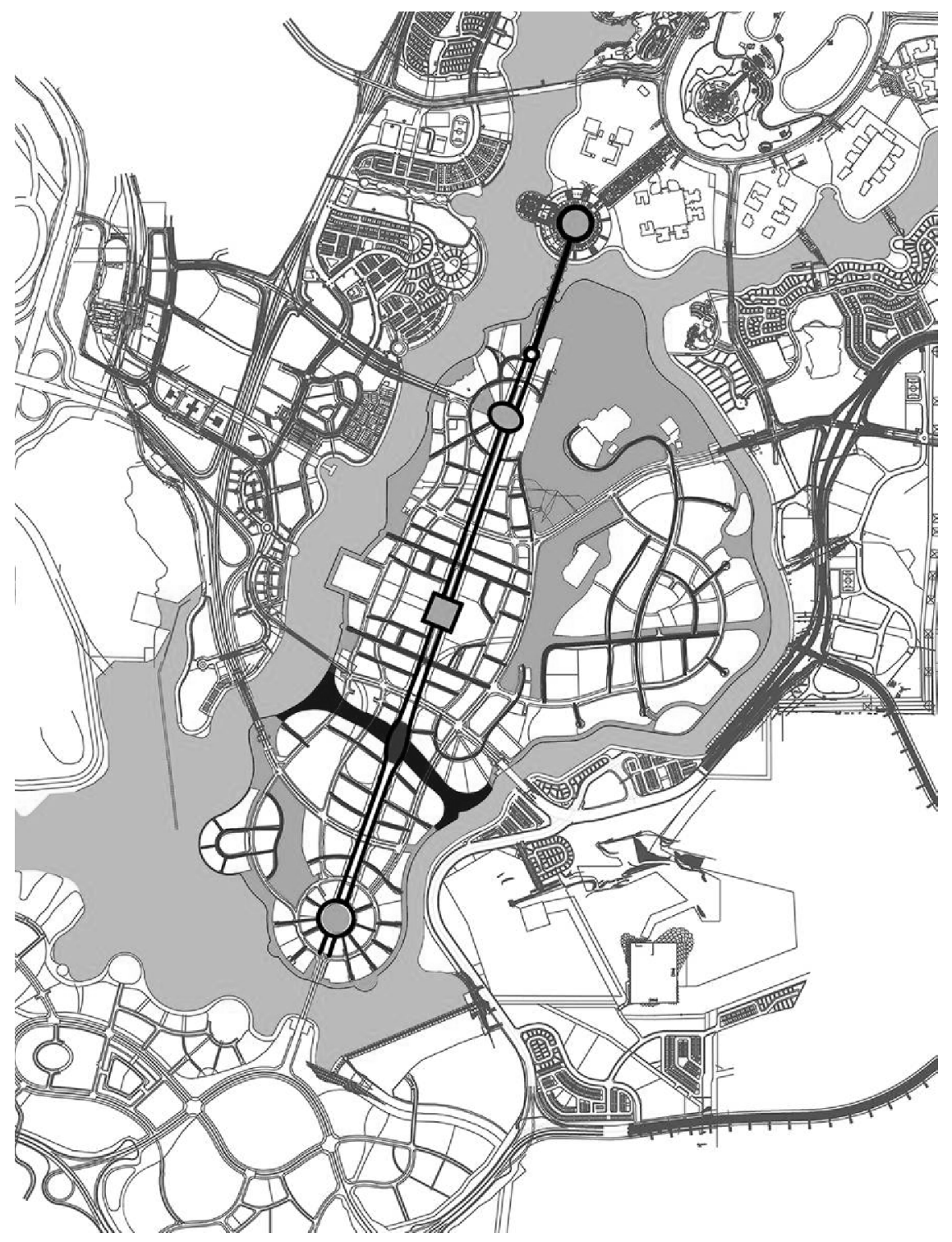

Figure 1: $\quad$ The core island of Putrajaya is surrounded by an artificial lake [2]. The proposed project is highlighted in the middle. 


\section{Issues}

The traffic volume of Putrajaya is expected to increase seven fold by 2025, contributing to an enormous amount of carbon emission by this operation alone. Putrajaya's effort to be a Garden City is backfiring as the maintenance effort to keep up its greenery is actually taking a toll on the environment. Both these unsustainable urban operations completely deprive Putrajaya from achieving its Green City status by 2025. Taman Rakyat itself was intended to celebrate our Prime Ministers, yet its effort is poorly presented.

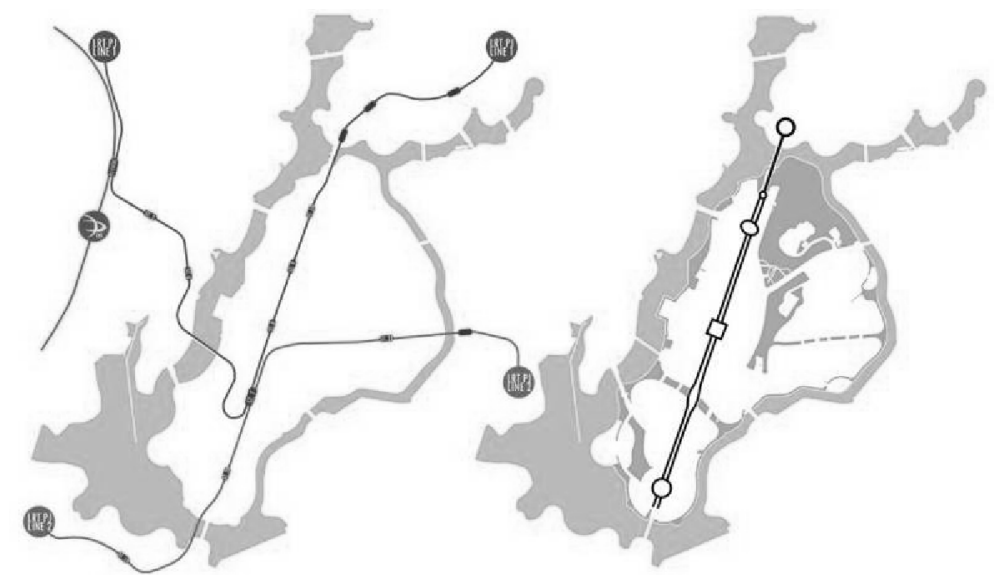

Figure 2: $\quad$ Putrajaya's core island precincts.

\section{Hypothesis}

The legacy of our Prime Ministers will resurrect through built form dedicated as public space to the people. The new orchard park will be the catalyst of an ecosystem resurrection by creating a hub for natural processes of pollination to become a self-sustaining park network. The new development will be the prime epicentre of Putrajaya as they can relax, works, live, eat and shop while contemplating the contributions of the Malaysian legacy within a premium connective hub.

\section{Strategies}

In order to guarantee success of this proposed development, a number of implementation mechanisms have been listed. The main stakeholder will participate together with other investors in a unique strategic partnership [3]. They consist of government and private organization associated with Putrajaya's development including Putrajaya Holdings and Perbadanan Putrajaya.

There are eight major groups that include the federal government and its agencies; resource and energy agencies; tourism, commercial, environment and 
health; agriculture and logistic partners as illustrated figure 3. Each component intersecting on top of the lines show a mutual consent between different parties.

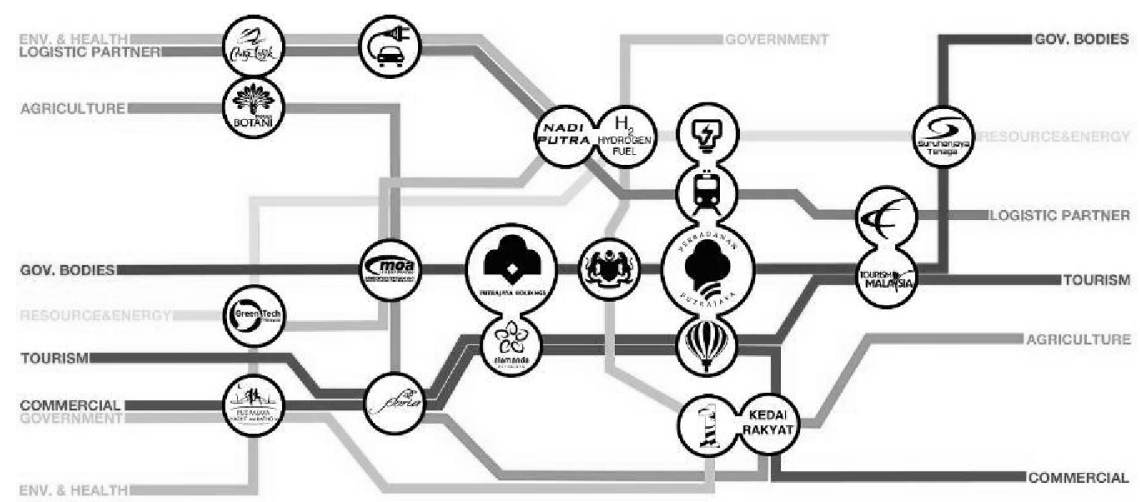

Figure 3: $\quad$ The collaborative networks between stakeholders.

\subsection{Instruments}

There are three main instruments used to execute the proposed development (figure 4). These instruments pose vital necessity that contributes to the general success of the scheme.

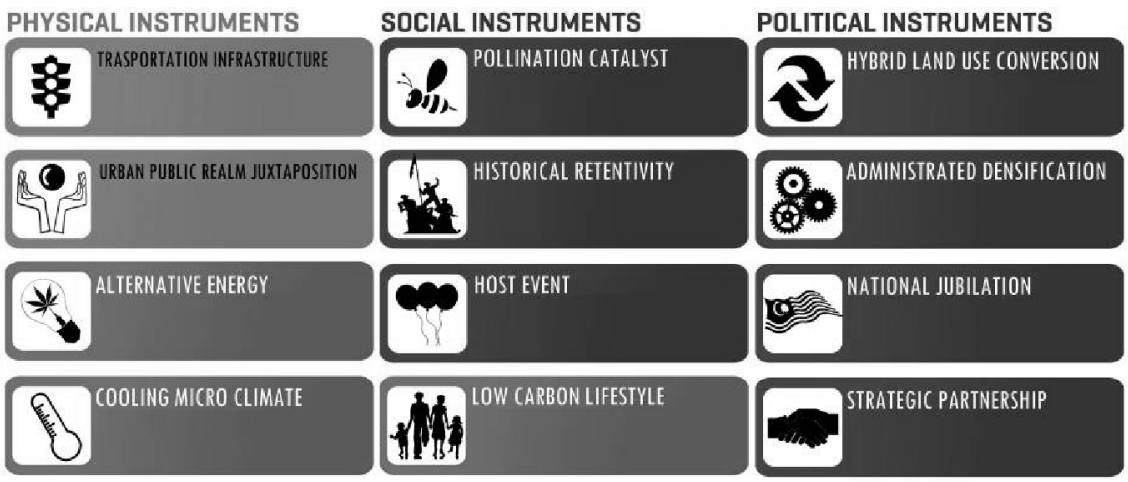

Figure 4: $\quad$ Introduction of urban and management policies.

\subsection{User program: mass mixture}

A variety of target users have been classified as commuters, local community and tourists. An analytical study of their daily activities has been transposed into a program base storyboard. Their activities and space requirement have been mapped out to suit their needs. For example, both local and foreign tourists can stay in hotels allocated in the east tower. In the afternoon they are able to enjoy the lush greenery on Taman Rakyat while they try the various traditional fruits 
along the orchard garden. Shopping and fine dining experiences are available in a wide choice of variety. From here they are able to catch a ferry taxi or a cruise to enjoy a one- hour ride around the lake of Putrajaya.

\subsection{Program zoning morphology}

The proposed urban intervention is established from direct respond to context relative zoning such as the major pedestrian network, connection between blocks, and by carving the entrance foyer and the waterfront square [4]. The program layering is based on neighbouring zoning and penetrating the traffic artery (figure 5).

The design started by zoning the potential programs and identifying the existing allocated land use near the site. The existing commercial surrounding is taken into the site to create a seamless shopping experience even when shoppers walk across the park. The next step was to identify projected potential pedestrian routes. This new pedestrian pattern will influence the movement pattern of the site through urban blocks, which later serve as circulation routes.

The development will consolidate by blurring the boundary of neighbouring sites so as to complement the surrounding development. At both ends of the waterfront, there are two open public squares that are carved in relation with the water body [5]. These semicircular bays provide longer perimeter view line of the waterfront.

Retails and commercial services are placed nearby the main roads, giving much needed exposure towards merchandise or product to the passing traffic. Small and mid size enterprises are inserted to support the surrounding development consisting of several mixed developments and residential blocks. Complimentary programs such as entertainment, leisure and sports are added to increase liveability.

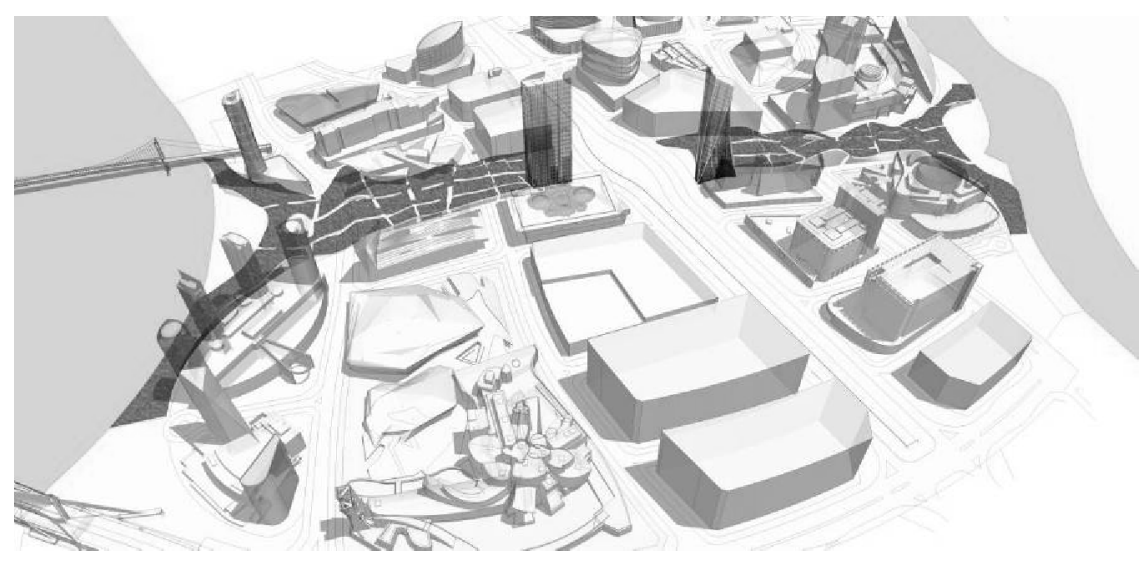

Figure 5: Aerial view of the proposed development that consolidate the adjacent blocks and the two main waterfronts. 


\section{Urban realm}

The development will maintain $70 \%$ of the landscaped area despite the large structure. This number accumulates to a figure of 16 acres of cultivated area and serves as a carbon sink within the city. The development is capable to absorb 28.6 tons of $\mathrm{CO}_{2}$ a year. The diverse variations of flora accumulate to 4809 different species and attract more than 700 native fauna as well. With the help of pollination, the lush greenery is expected to increase to about $32 \%$ more than ordinary planting methods.

\section{A national tribute to Malaysia’s legacy}

The public urban realm is divided into two major components. First, is the Prime Minister inspired urban space that serves as unique nodes along the spines. The surface of this spine creates the second component, a large continuous park build for the people that connect all the nodes together. The legacy of our Prime Ministers will be resurrected through built form dedicated as public space to the people. This permanent tribute encompasses the contributions of these great leaders and manifests them into abstract urban spaces along the new park that enhances Putrajaya's walk ability.

\subsection{Taman Rakyat: Park of the People}

A process of formation through archipelago or islands, sparking new opportunity for the park future created the new park along the newly created axis of the people. The formation of these building blocks that formed the islands is a direct respond of the existing building form, urban connection and programmatic configuration. This island consists of 4 main typologies, as shown in figure 6 .

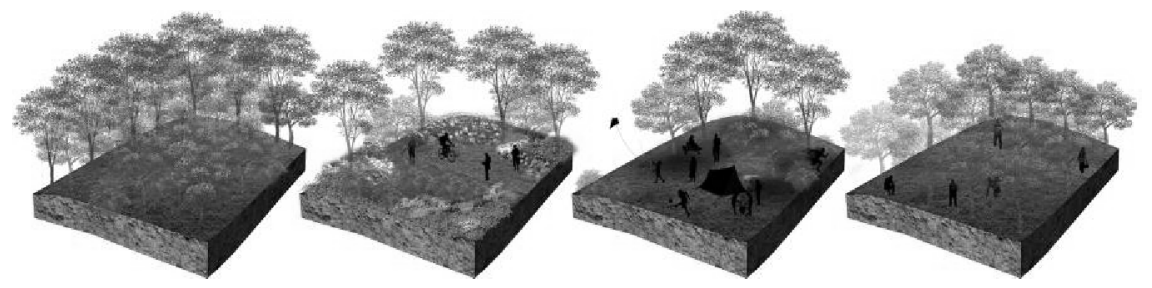

Figure 6: The typologies of the archipelago blocks that form the Park of the People.

\subsubsection{Isolated and steep islands (rainforests)}

Totally inaccessible with extremely steep slopes; not recommended for any program and highly dangerous to public. It is the main carbon sink area and animal habitat.

\subsubsection{The long and gentle slope (flower enclave)}

The undulating landscape and gentle slope of the land give a relaxing walk; provides a lot of relaxation and leisure activity potential; suitable for gardening and recreational activities. 


\subsubsection{Open flat delta (turf field)}

An almost flat land with large open space; the surface is large enough to hold and host a lot of outdoor recreational activities.

\subsubsection{Interconnected islands (fruit orchard)}

Fairly accessible from all other island; suitable to be the prime program host of ecosystem revival. Fruit orchard provides urban dwellers the opportunity to enjoy fresh grown fruits.

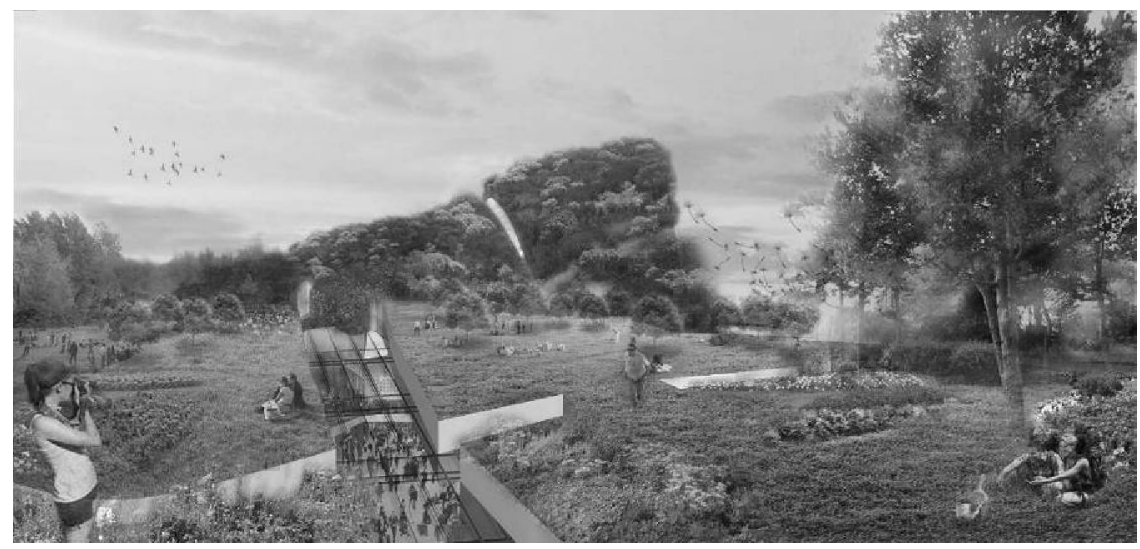

Figure 7: $\quad$ Taman Rakyat, Park of the People.

\subsubsection{Green City 2025}

The whole urban project was grounded on a sustainable development for the city. Since its inception stage, various green design strategies have been moulded for the entire program. Figure 8 shows a few green design systems such as internal courtyards, large opening towards the lake for natural cooling and air filters on the roof to ensure sufficient indoor environment quality. Other measures undertaken for the development such as double volumes to promote natural ventilation, water bodies to keep interior temperature low, under floor cooling and rainwater harvesting systems. A few technical aspects have been injected to realize a future green city such as algae farms for cars that run on hydrogen as well as a stack car park that runs simply by hydraulic pressure from the lake.

A huge measure of a sustainable system has been the driver and the main backbone of the entire scheme. In relation to the active and passive space design maximum consideration has been taken towards generating a responsive living in a tropical climate. This massive development in Putrajaya's core island will be a major contributor for Putrajaya to achieve its green city status by 2025 .

\subsection{Tunku Abd. Rahman: Oval of Independence}

The Oval of Independence (figure 9) is a formal plaza dedicated to Tuanku Abdul Rahman as he brought the nation to its independence in 1957. This space has a semi circular seating overlooking the lake, the Tuanku Mizan Zainal 


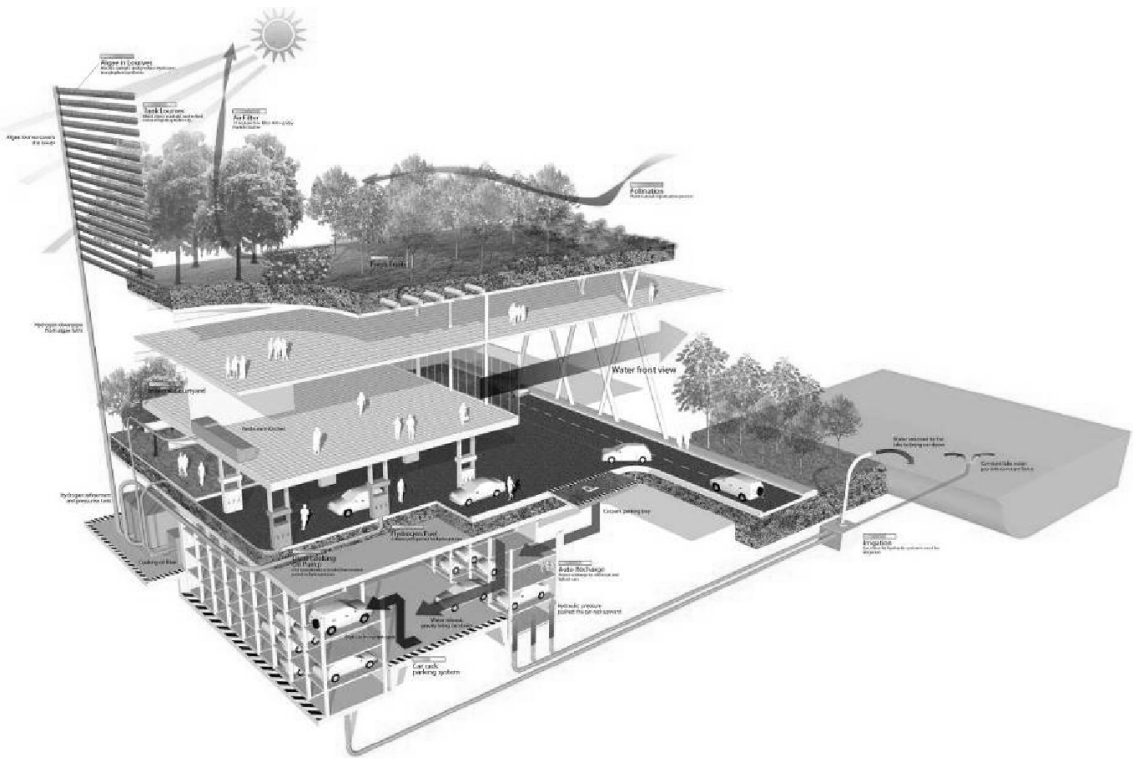

Figure 8: $\quad$ Sustainable design features.

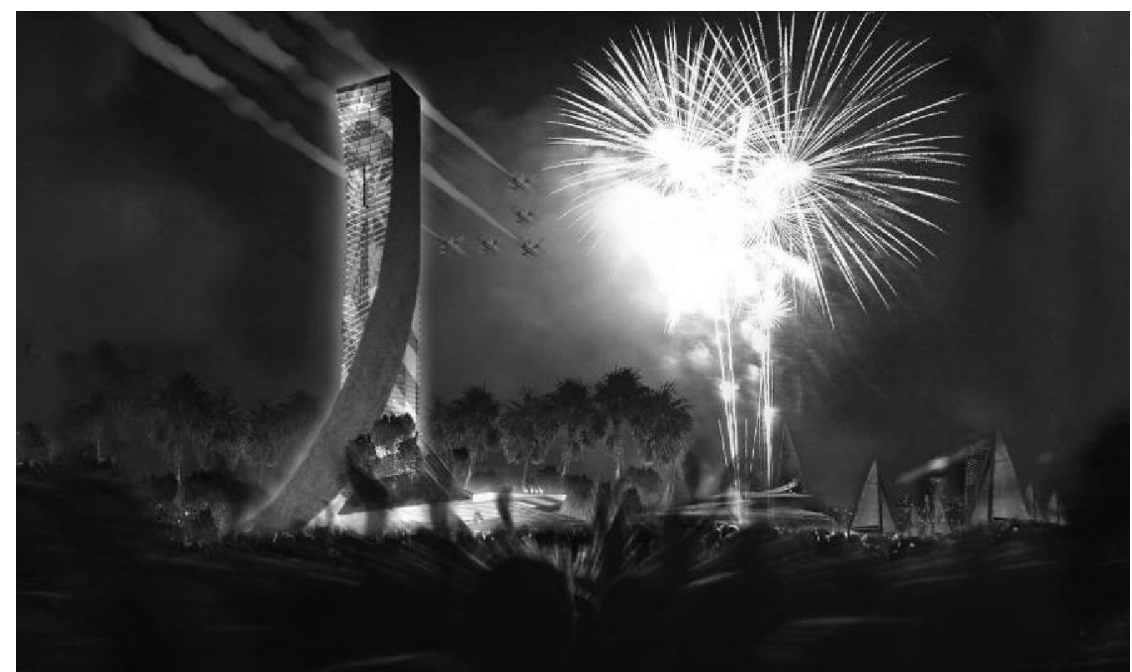

Figure 9: $\quad$ The celebration of Independence Day at the Oval of Independence.

Abidin Mosque and the Seri Saujana Bridge. The ambience portrays openness and freedom, reminding Malaysians to be grateful for achieving independence and living in such harmony until today. During an ordinary day, the host small retail kiosks, lakeside cafes, a chess park and waterfront picnic pods. Its oval 
shape allows maximum viewing for any formal events, such as the annual Flower Festival and Independence Day Celebration.

\subsection{Tun Abdul Razak: Spire of Progression}

The Spire of Progression is an environmental cone dedicated to Tun Abdul Razak, the Father of Development. The form of the spire derives from an upward movement, resembling the nation's progression towards a bright future. This is the most significant component that makes Malaysia what it is today was introduced during the tenure of the second prime minister, Tun Abdul Razak. Townships spruced up during his time, including Petaling Jaya, the country's first satellite town. Razak charted the development of the nation physically, politically, socially and economically [6]. The after-effects of which are felt and witnessed to this day. The Spire of Progression is a sophisticated space with various technological advancements. The inner shell of the spire is overgrown with wall creepers allowing natural light to be filtered before it penetrates the space. The outer ring is fitted for wall climbing activities and a sunken cafeteria is also located nearby for public to dine and socialize while their children play in the playground, located in the center of the spire.

\subsection{Tun Hussein Onn: Amphitheater of Unity}

The amphitheatre is dedicated to Tun Hussein Onn, the Father of Unity. Therefore the idea and concept of this space involves much with the unification of a wide range of people together in one location no matter what age or race. The huge amount of people it accommodates enables them to interact with one another while enjoying the facilities it has to offer.

The amphitheatre is the main informal event host located on the east side of the development, where the waters are much less busy than the open water body on the west side. Here, a simply carved semi circle is converted into an open-air amphitheatre. The movable floating event pod is a floating stage hosting concerts and screenings so that the audience gets a full viewing pleasure without any obstructions. LED pixilated floor provides extreme versatility of event presentations. The beautiful background and the traffic isolated location enables reality shows to broadcast live coverage. The wide variety of possibilities to transform the amphitheatre into multi functional spaces contribute to a sustainable development as no wastage of space occurs for occasional events.

\subsection{Tun Dr. Mahathir Mohamad: Point of Vision}

Vision 2020 is a Malaysian ideal introduced by the former Prime Minister of Malaysia, Tun Mahathir Mohamad during the tabling of the Sixth Malaysia Plan in 1991. The vision calls for the nation to achieve a self-sufficient industrialized nation by the year 2020, encompassing all aspects of life, from economic prosperity, social well-being, educational world class, political stability, as well as psychological balance.

The Point of Vision manifests the visionary thinking of Tun Dr. Mahathir Mohamad when he set a goal for Malaysia to be a developed nation by 2020 . 
One of his instruments in order to achieve these set of goals, was the birth of the administrative capital city of Putrajaya. Despite many objections and different views about Putrajaya, the city will eventually take its shape with a brand of a Malaysian city. The observatory deck is made of panels of windows with integrated smart glass features. This glass has electrical current passing through them, enabling to act as screens. These screens show a rendered video of Putrajaya just as Tun Mahathir envisioned it to be through his eyes. This space is on the highest elevation of this development and it is situated nearest to Dataran Rakyat. Visitors will be able to see Putrajaya from birth to completion, as the glass slowly fades, and the current state of Putrajaya can be seen from the any point of vision.

\subsection{Tun Abdullah Ahmad Badawi: Fountain of Inner Peace}

The Fountain of Inner Peace (figure 10) lies within the premises of the transportation hub, and functions as a main waiting area. It acts as a solitary enclave which provides ample space for social and learning activities within its public space for daily commuters and other users as it is located near the public transportation hub. The fountain consists of 3-tiered sunken plazas, each with its individual privacy gradient facing the Fountain. The deepest plaza has the highest privacy level, as it is located nearest to the water body and the fountain, named the Reflection Ring as it is in this area where Tun Abdullah's Poem can be heard.

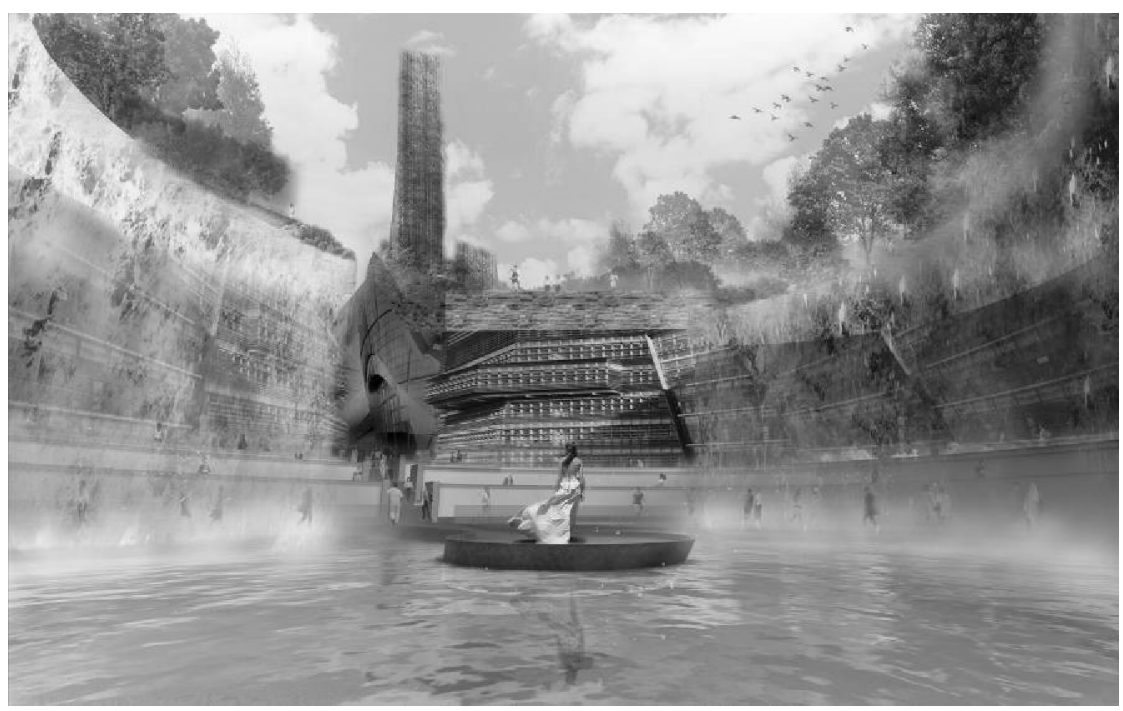

Figure 10: Fountain of Inner Peace. 


\subsection{Dato’ Sri Najib Abd Razak: Dataran Rakyat}

Dato’ Sri Haji Mohammad Najib bin Tun Haji Abdul Razak is the current Prime Minister of Malaysia since 2009. As this urban development was proposed during his appointment as Prime Minister, the Dataran Rakyat will be dedicated to him as it represents the starting point of the development as it expands to both east and west ends. Dato Sri Najib stresses national unity and ethnic tolerance through the 1Malaysia campaign. The 1Malaysia slogans give emphasis on the people (rakyat) and therefore 'Dataran Rakyat' of Putrajaya will be a dedication to him when he steps down of the office and steps in as the 6th legacy of Malaysia.

\section{Conclusion}

The project will become Putrajaya's crown jewel as an exemplary development that embodies the Garden City concept. The closeness between man, and nature in an urban setting enhances living quality and liveliness [7]. The prime minister inspired public spaces become an urban culture melting pot where people from different races eat, shop and work with deep appreciation to the leaders. The new park will not only become the green lung of Putrajaya, but also enhance biological network of pollination processes to affect other parks on other parts of Putrajaya, thus creating a sustainable city by 2025.

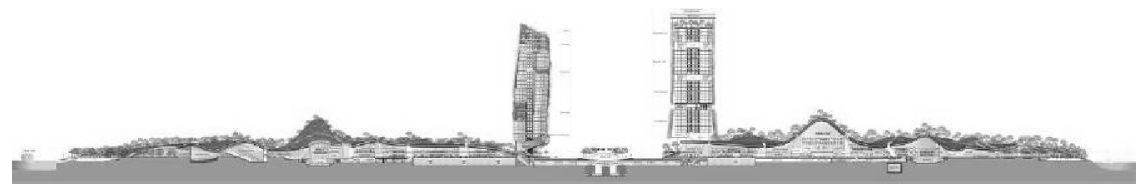

Figure 11: Full stretch longitudinal section.

\section{References}

[1] S.S Zubir and W.A. Sulaiman, 'Deciphering urban cultural heritage, community and the city', in Marchettini, N., Brebbia, C.A., Tiezzi, E. and Wadhwa, L.C., The Sustainable City III, Southampton: WIT Press, 2004.

[2] Urbanisma Architect Sdn. Bhd., Putrajaya Detailed Urban Design Conceptual Design Report Malaysia, 1998.

[3] Kerry McGovern, Accounting's Contribution to Sustainable Cities, K McGovern \& Associates, 2010.

[4] Hijjaz Kasturi Associates Sdn. Bhd., Irrigation Masterplan for Putrajaya Volume 1 and 2 Malaysia, 1999.

[5] S.A. Rahman, R.M. Khalid and R. Sahat, Sustainable Water Management: A Case Study Of Putrajaya Malaysia, Universiti Putra Malaysia, 2010.

[6] S.K. Nasution and A.R. Lubis, Kinta Valley Pioneering Malaysia’s Modern Development, Ipoh: Perak Academy, 2005.

[7] Ken Yeang, The Architecture of Malaysia, Amsterdam/Kuala Lumpur: The Pepin Press, 1992. 